\section{犬における胎児の浸漬と腸閉塞の 合併症例}

\author{
金田弘倫*
}

晹閉塞学疑引に足尚症状が所見されたにかかわらず, 胎児の浸漬による子宮膨隆のため, 腹部触診上, 確認困蜼 であった例症を経験したので，献告する。

\section{(1) 毫告の概要}

犬種 中型雑種, 雌, $3 才$.

病歴 生後11力月にジステンパーに患ったほか, 幼犬 期に 3 度駆出乙ただけで，きわめて頑健であった。

歴歴生後17力月と25力月の2回，それぞれ 3 頭之5

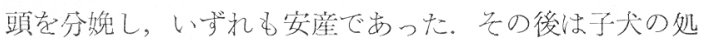
分飞苦学するので，発情期には注意して野合の㙨会を防 止していた。

33年10月初旬邸内に侵入乙た婎上交尾，11月に入って 腹部が大きくなり，11月末頃には外見上明らか胎動を 譛めたが，12月10日に至って子分婏求ず，中白頃上り少 しく腹部の縮小したよ5に記憶吉る。その間，きわわて 元気でなんら異常は認められなかったが，12月26日より 食欲減衰孝認义, 翌日には全く排絶儿, 排便は正常, 便 少量老見た。28，29日は元気な寸束与減衰し，排便なく

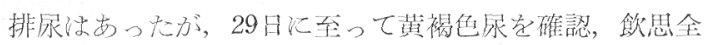
くない，30日に至り乳白泥状叶物をかなり多量連続 3 回

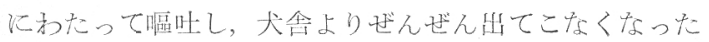
ので来診をこうた。

\section{(2) 初診時の所見}

T $38.4^{\circ} \mathrm{C} . \mathrm{P} 120$ 。元父沈衾, 歩様は後肢の踏达又浅

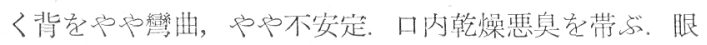
結膜充血軽度，胸部，心部は聴讋上とく飞異常寺認めな い, 腹部起触診する飞子宮の鮥隆を認めた。綿密に触 䛦, 聴診する飞胎児の心音全くなく, 子宮の波動老認む るも胎児の骨格を触知し得ず。胵口和よび臸内孝検する も子宮よりの和りもの老認められなかった。試又に水を 与えて見たが领思なく、さらに腹部の触骖を行ったが， 子宮膨隆にさむたげられて，腸の状態をよく知ることが できない。たまた艮診中晹叶を催し，少量の乳状叶物 を見たので検したところ，腸内容涀られる恶臭袁寡び て怙り, 腸蠕動音やや正常より強い部分を認めた。試又 にグリセリン浣晹起行らも便意のみにて排健をみない。

以上の所見より子宮蓄膿症と腸閉塞，またはこれに近 いなんらかの異常があるものと判断し, 開腹手術孛行。 た。

\section{(3)手術の結果}

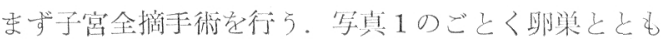
* 茨木市大字茨水 1657 開業
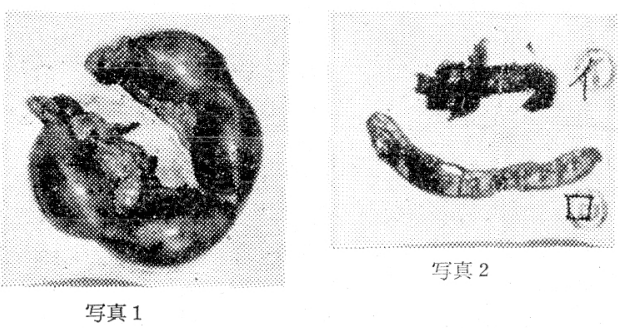

に左右にそれぞれ 2 胎児ずつを蔵した子宮角を引出した ところ，創口より腸の一部が押出されてきた。その部の 腸間膜が充血しているのに気付き，さらに腸学当泏して 調ベたところ，廻腸中央部に写真 2 口のごとく長さ約 10 $\mathrm{cm}$ にわたって暗紫尔色, 壇死化した腸閉塞部老発見し た。従って早急飞子宮体中央で子宮毒切断䋖合のら党, 引続き廻腸閉塞部を切開し，内容を摘出したところ写真 2イのごとき不消化昆布巻を認めた。閉塞部腸管は閉塞 部孝中心として約 $20 \mathrm{~cm}$ にわたって溒死化し, 附属淋巴 腺はいずれも小豆大以上飞嗹脹充血，腸間膜所々飞点状 出血を認わたので，思い切って切除し，両断端学閉鎖盲 端上なし，側々吻合法による吻合，さらに腹腔内圭りン

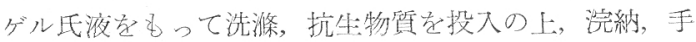
衔を終了した。

摘出子宮堂外部より㭘查するに死胎罗の内藏老触知し たので，刀をもって牙開し，内容を調べたところ，流動

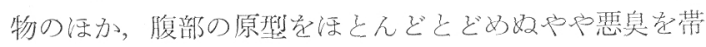
びた融解死胎学認めた。な牧父腫胎のごとく腫大軟化並 びにははなはだしき悪臭索認めなかったので，骖断で子 宫蓄膿症と判断したが，胎児の浸漬であったことを確諗 した。

\section{(4) 予 後}

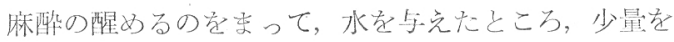

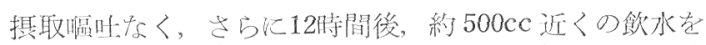

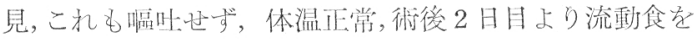
とり，4 日頃より便質潄次硬化し，爾後経過良好，8日 日に拔絭した。

\section{(5) 所 見}

1) 過去腸閉塞症は開丵 4 力年中 6 例（他に重量症 4

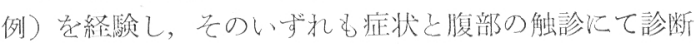
がついた。 5 ち1例は下剤之浣晹比よって内容の排除に 成功し, 他の5 例は外科的飞摘出し, か心いずれも腸壊 死を伴ったものはなかったので, 腸壁切開による内容物 の摘川にて日的を澾した。

2）過去の腸閉塞の内容物は 6 例中 5 例が石塊， 1 例 が乎骨版岕った。昆作巻によるのははじめてで, 昆布

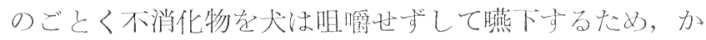
かる絃果走招いたものと考克る。

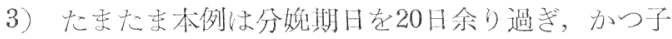

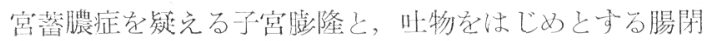


塞症を疑える症状を認めたので, 思い切って開腹手術に 着手し好結果に終ったのであるが，もしこれが正常妊娠 犬であり，かつ高価な交配料を費されている場合，こう も思い切った処置はとれなかったと思う。また症状の明 かになるまで見送るとか，消極的な態度をとった場合に 予想される患犬の辿る結果を種々想像すると，小生は冷 汗を禁じ得ないので，浅学をかえりみず本交を稿した次 第である.

\section{犬の外耳炎の 1 治 験 例}

滰 川 浩*

慢性化した外耳炎の 1 治験例について報告する.

患畜 シェパード, 雄, 2 才.

禀告和よび症状 昭和 33 年夏頃より左側外耳炎の症状 を示して頸を振り, 後肢で耳側をかき, 疼痛を訴えると の主訴で加療を求められた。

外耳内側を綿棒で清潔汇して扣き，オーレオマイシン 軟高の注入をして执いたが, 病状ははか㤝かしくなかっ

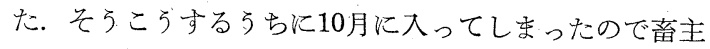
より根本的の治療をして下さいと申込亲れた。左右両側 に病状が現われているので, まず外科的処置を取り，次 いで創面の治癒後において外耳炎の残存部位の治療をす ることに決定した.

* 鎌倉市材木座 開業

\section{手術}

外科的処置は米倉氏（日獣会誌，40,9, 1956) 記載の 術式を応用した。いわゆる外耳外側被毛部に执けるV字 状切開術で，患犬を全身麻酔下に括いて，アドレナリン 加， $0.5 \%$ プロカインを術野全部执よび求心部に多量止 血の意味で前処置をして扣く．長目の桿子を切除部の外 側に圧定して, 後に外科刀で中央を切開; 終点まで切り 下げて患部の異状のない点まで延長切開する.

次いで圧定桿子を装定した部分の軟骨招よび皮膚を切 除する、な扣この場合軟骨は創面より $5 \mathrm{~mm}$ 位の巾で多 く切除して創の癒合を早めた。慢性化して各突起が相互 飞接触し，そのところに潰瘍面を作る場合が多いので， このようなことが慢性化の原因の1つであると思われる ので, 突起の基部より切除して止血（焼ゴテ）する. 後 は粘膜面の縫合は血管針を使用して結節縫合として，一 般の外科的処置と同様にする. 抜糸は粘膜面であるので 早い場合は 4 日目位より間引しながら抜系を行い， 7 9 日で全糸を抜いてしまらことができた。そ間の治療 は他の外科的創傷の場合と同様である.

\section{結果}

一応手術創面の治瘾した後外聴道内に幾分炎症部を認 めたので Oticole を外聴道内に $0.3 \sim 0.5 \mathrm{cc}$ 位を注入し 外部よりよくマッサージしてペニシリン30万単位を筋注 した. 2 日間隔で 5 回の使用で十分に目的を達したので ある. 同時に手術創面は完全に治癒してきたので, 本治 療は終了した。

参考文献

1) 米倉忠夫：日獣会誌，40，9(1956)，2）二：同誌，74,2(1959)

\section{[地方会便り]}

\section{大阪}

狂犬病予防業務委嘱獣医師慰楽会の催し 大阪府上り 昭和 33 年度狂犬病予防業務の委嘱を受けている開業獣医 師 39 名に対し年度中予防注射, その他の業務に精励し た，その労を称ぎらうためこれに来賓10数名を加え，去 る 3 月 15 日午前 11 時より午後 4 時まで大阪道頓堀中座に 扔いて開演中の「大江美智子劇」観劇飞招待し, 会員中 数名はご家族ご同伴の円満振楽しい半日を過した.

第11回通常総会の開催 3 月20日午後 1 時より大阪府 警和虹坓（大阪市東区大手前町）を会場として本会第11 回通常総会を開催し, 参会々員48名; 中村副会長司会の もとに, 榎原会長の挨拶, 大阪府農林部長 (手塚係長代 理) 大阪動物愛護会長（辻理事長代理）らの祝辞ありた る後直ちに議事に移り, 榎原会長議長席につき下記報告 事項および提出議案をそれぞれ附議慎重審議し, 各案と も满場一致承認または原案ど招り可決した。

（1）昭和33年事務並びに事業報告について。 (2) 昭和 32 年度本会普通並びに特別会計収支決算承認について。
（3）昭和 33 年度本会普通会計収支追加予算について．（4) 昭和 34 年度本会事業計画について。（5）同年度会費額亚 びに分賦収入方法について。(6) 同年度本会普通並びに 特別会計収支予算について

ついで任期満了に伴う本会役員の選挙を行い, 会長拉 よび副会長は例年ど㧍り出席者の無記名投票にょり, 理 事, 監事は総会の議決を経て 7 名（各支部より 1 名）の 詮衡委員会飞打いて詮衡の結果会議に諮り当選者を次の 通り決定した。

会 長 榎原義一

副会長 中村 寛 青木竜身

理 事 榎原義一 中村 寬 青木竟身 塩谷 正 既我部要 永田正弘 金田勝之 原耕章 岩田千虎 西田梅雄

監 事大道鷿夫川面清次 路次春彦

な就引続き社団法人日本獣医師会役員候補者推蔗につ いてそれぞれの候補者を満場一致選定することに決定 し，午後 5 時 10 分会議を閉じ散会した。

[大阪 榎原義一記]

日獣会誌 12 (1959) 